\title{
上腕二頭筋の運動単位数の計測と その臨床応用に関する研究
}

\section{近 藤 健*}

- Key words : 運動単位 (motor unit), 筋電図 (electromyogram), 頸髄損傷 (cervical spinal cord injury), 上腕二頭筋 (brachial biceps muscle), 四肢麻痺 (quadriplegia)

要氜

\section{上腕二頭筋の運動単位数の計測と その臨床応用に関する研究}

\section{近藤 健}

健常 102 肢および頸髄損傷（残存機能レベル $\mathrm{C}_{5} \sim \mathrm{C}_{7}$ ) 12 肢の上腕二頭筋におい て，針電極の運動単位電位をトリガー信号とし，表面単一運動単位電位を加算平均 により計測し，最大M波と比較し運動単位数を算出した。また，表面電極の形状と 貼付位置, 再現性について検討した. 健常者の運動単位数は, 60 歳を越えると有意 な低下が認められ, 60 歳以下では $631 \pm 219$ であった.頸髄損傷患者の残存運動単位 数は，筋力が低下しているほど減少し，徒手筋力テスト 3 レべルの 3 肢ではすべて 100 以下となった。本法は頸髄損傷患者の部分的脱神経の定量的評価が可能であり， 筋力回腹の予測，そのメカニズム究明，筋力増強法の検討に有用と思われる.

\section{I八医学 $32: 367-375,1995$}

\section{はじめに}

人の筋における運動単位数の計測は, 加齢あるいは 神経・筋疾患における筋力低下の病態究明，さらにそ の進行や回復過程における予測, 評価に不可欠である. 運動単位数の計測法には組織学的方法 ${ }^{8,10,18,29)}$ と電気 生理学的方法 ${ }^{23,25)}$ があり, 後者は臨床応用が可能で, 現在，特定の筋の運動単位数を計測する方法として刺 激漸増法 ${ }^{24)}$ とトリガー法7)が報告されている. 今回, 著 者はトリガー法を用い，まず上腕二頭筋の運動単位数 計測法に関する基礎的実験を行い，次に健常者におけ る加齢に伴う運動単位数の変化，さらに頸髄損傷患者 における運動単位数の計測について検討し興味ある結 果が得られたので，若干の考察を加えて報告する.

\section{対 象}

\section{1 運動単位数計測法における基礎的検討}

\section{1 ）表面電極の形状の影響}

健常成人男子 7 人 (23〜 41 歳, 平均 26.6 歳) の上腕 二頭筋 8 筋（右 4 , 左 4 ）を対象とした.

\section{2 ）表面電極の位置の影響}

健常成人男子 9 人 (23 41 歳, 平均 28.9 歳) の上腕 二頭筋 10 筋（右 5 , 左 5 ) を対象とした。

\section{3 ）運動単位数計測の再現性}

健常成人 6 人 (26 50 歳, 平均 32.1 歳) の上腕二頭 筋 10 筋（右 5 ，左 5 ）を対象とした。

1994 年 11 月 28 日受付, 1995 年 3 月 7 日受理

*慶應義塾大学医学部リハビリテーション科/テ 160 東京都新宿区信濃町 35 


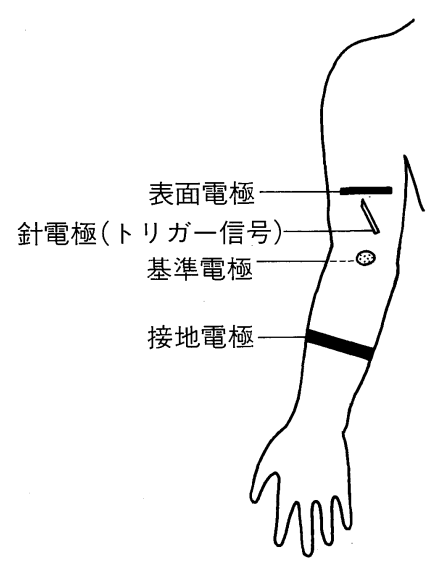

図 1 電極の配置

$8 \mathrm{~cm} \times 2 \mathrm{~cm}$ の銀板の表面電極を上腕二頭筋の運動 点中央に筋線維走行と直角に, 基準電極は肘頭部に, 接地電極は前腕部に配置した。計測する運動単位の トリガー信号を導出する同芯針電極は, 表面電極よ り $1 \mathrm{~cm}$ 末梢の上腕二頭筋内に刺入した。

\section{2 健常者の運動単位数の計測}

被検肢に明らかな神経・筋疾患を認めない 20～92 歳 の 102 人の上腕二頭筋 102 筋（右 48, 左 54 ）を対象と した. 年齢構成は, 20 歳から 10 歳区切りで順に 20 人 (男 12 , 女 8 ), 13 人 (男 7 , 女 6 ), 14 人（男 6 , 女 8 ), 11 人（男 5 , 女 6 ), 15 人（男 8 , 女 7 ), 15 人 (男 6 , 女 9 ), 13 人 (男 5 , 女 8 ) および 90 歳以上 1 人（男1）であった.

\section{3 頸髄損傷患者の運動単位数の計測}

頸髄損傷による残存機能レベルが $\mathrm{C}_{5} \sim \mathrm{C}_{7}$ の運動麻 痺患者 8 人（男 6 人，女 2 人，20～ 65 歳）の上腕二頭 筋 12 筋 (右 6 , 左 6 ) を対象とした。被検筋の筋力は 重力に抗して时関節屈曲が可能である徒手筋力テスト (manual muscle test ; 以下, MMT と略す) 3 レべ ルが 3 肢, 軽度の筋力低下がある MMT 4 レベルが 6 肢，筋力が正常の MMT 5 レベルが 3 肢であった. 頸 髄損傷患者はすべて受傷後 6 力月以上を経過した慢性 期の患者であった.

\section{方 法}

\section{1 運動単位数の計測法}

上腕二頭筋において，まず表面電極を用い筋腹表面 より最大誘発電位 (以下, 最大M波と略す) を計測し,
次いで表面電極と針電極を用いてトリガー法により， 10 個の表面単一運動単位電位（surface single motor unit potential ; 以下, S-MUP と略す) を計測し, 最 大M波の振幅を S-MUP の平均振幅で割って運動単 位数を算出した.すなわち運動単位数は以下の計算式 により算出した.

$$
\text { 運動単位数 }=\frac{\text { 最大M波の振幅 }}{\mathrm{S}-\mathrm{MUP} \text { の平均振幅 }}
$$

最大M波および S-MUP の計測は被検者を安静臥 位とし时関節は伸展位にて行った. 表面電極は後述す る基礎的実験データに基づいて長さ，幅を検討し，自 家製の $8 \mathrm{~cm} \times 2 \mathrm{~cm}$ の矩形銀板を用いた，表面電極は 筋腹上に長軸が筋線維の走行と直角となるように貼付 し，基準電極は血電極を用い肘頭部に貼付した(図 1). 皮膚を安全剃刀により剃毛し,さらに，目の細かい紙 やすりによる清拭により, 両電極のインピーダンスを $20 \mathrm{k} \Omega$ 以下となるまで落とした，接地電極は前腕部に 配置し，フィルターは $2 \mathrm{~Hz} \sim 10 \mathrm{kHz}$ とした.

最大M波は，筋皮神経を腋下部の上腕二頭筋短頭筋 腱背側にて刺激電極の陰極を末梢側に置いて，徐々に 刺激強度を上げて最大上刺激により記録した（図 2A). 続いて S-MUP を測定するために, 特定の運動 単位のトリガ一信号を導出する目的で, 直径 $0.3 \mathrm{~mm}$ の同芯針電極を表面電極より $1 \mathrm{~cm}$ 末梢の上腕二頭筋 内に刺入した．針電極のフィルターは， $500 \mathrm{~Hz} \sim 10$ $\mathrm{kHz}$ とし, 針電極からの電位をチャンネル 1 , 表面電 極からの電位をチャンネル 2 として導出した.

S-MUP を測定するにあたり，被検者の时関節を伸 展位で保持し, 検者が被検者の前腕末梢部に軽く抵抗 を加え，上腕二頭筋を微小収縮させた．針電極から導 出した運動単位電位をモニターで見ながら，単一の運 動単位電位の頂点が上下の境界線内に入るように境界 線を移動して window の位置を設定した（図 2-B）. 安定したトリガー信号が得られていることを確認した 後, 表面電極から導出した筋活動電位の加算平均を開 始した. 加算平均はトリガー信号を中心とした $100 \mathrm{~ms}$ 間で行い, 波形に変化がみられなくなるまで行った(図 2-C）. 良好な S-MUP 波形を得るためには, 100〜500 回の加算回数を要した (図 $\mathbf{2}-\mathbf{a} \sim \mathbf{j})$. 電気刺激による 最大M波と 10 個の S-MUP はともに陰性-陽性の二 相性となり，振幅の計測は最大M波において電気刺激 による影響がなく， S-MUP において計測が容易であ る陰性頂点と陽性頂点との差を採用した。 なお，本研 

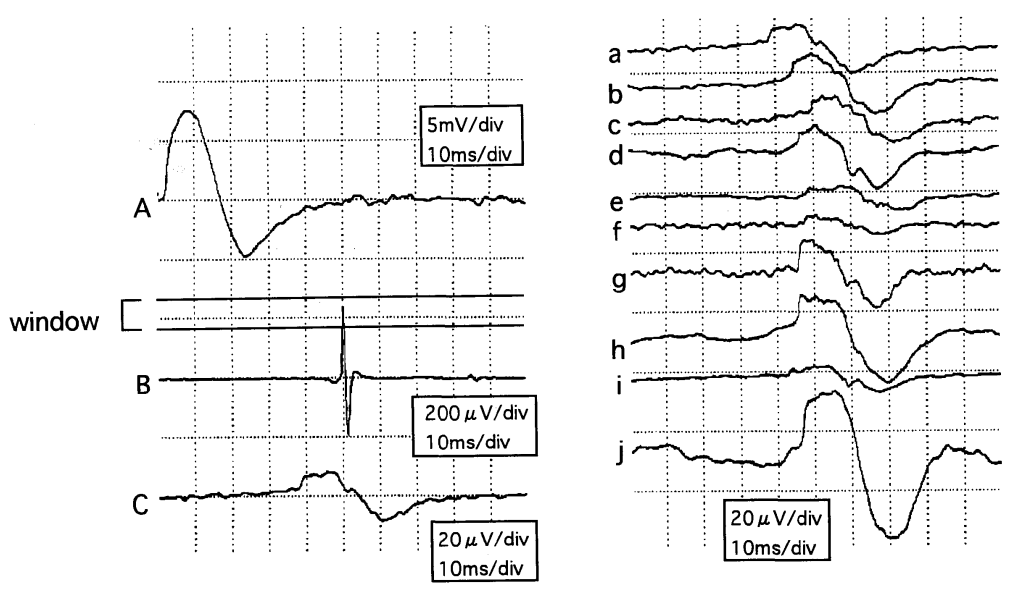

図 2 最大M波, トリガー信号および表面単一運動単位電位 (S-MUP) (34 歳, 男性)
$A$ ：腋下部で筋皮神経を刺激して得た最大 $M$ 波（振幅は peak-to-peak で測定し， $12.4 \mathrm{mV}$ ). B : トリガー信号として䆃出した針電極からの運動単位電位を加算平均した運動単位電位. 波形上下の境界線
に挟まれた window 内に運動単位電位波の頂点が入るとトリガーがかかり表面記録電極から導出した表面筋 活動電位の前後 $100 \mathrm{~ms}$ を加算平均した.
C：Bの運動単位電位波をトリガーとして表面電極からの表面筋活動電位を加算平均して得られた S-MUP.
$\mathrm{a} \sim \mathrm{j}$ : 上腕二頭筋から得られた 10 個の S-MUP (peak-to-peak 振幅は $3.4 \sim 51.2 \mu \mathrm{V}$, 平均 $18.9 \mu \mathrm{V}$ ). 最大 M 波の振幅を 10 個の S-MUP の平均振幅で割り, 運動単位数は 656 と算出された。

究に用いた計測機器はニューロパック $8^{\circledR} \quad$ （日本光電 社製）であった。

\section{2 運動単位数計測法における基礎的検討}

\section{1 ）表面電極の形状の影響}

表面電極は，長さが同じで幅が異なるもの 2 個 （8 $\mathrm{cm} \times 2 \mathrm{~cm}, 8 \mathrm{~cm} \times 0.5 \mathrm{~cm})$ と，幅が同じで長さの異な るもの 3 個 $(8 \mathrm{~cm} \times 0.5 \mathrm{~cm}, 4 \mathrm{~cm} \times 0.5 \mathrm{~cm}, 2 \mathrm{~cm} \times 0.5$ $\mathrm{cm} ）$ の 2 組の矩形電極を用いて，その形状の影響につ いて検討した.クロナキシーメーターにて運動点の位 置を探し，表面電極が運動点中央に位置するように貼 付した．また，各組の電極は $0.5 \mathrm{~cm}$ の間隔を空け，電 極の長軸が筋線維と直角になるように貼付した。針電 極はチャンネル 1 に，また，各表面電極は 2 〜 チャ ンネルに接続し，同時に最大M波と 10 個の S-MUP を計測し，それぞれの表面電極ごとに運動単位数を算 出した.

\section{2 ）表面電極の位置の影響}

$8 \mathrm{~cm} \times 0.5 \mathrm{~cm}$ の 3 個の矩形電極を長軸が筋線維と 直角に運動点の中央から中枢方向へ $2 \mathrm{~cm}$ 間隔で貼付 し，上記と同様に最大M波と 10 個の S-MUP を計測 し各位置ごとに運動単位数を算出した。

\section{3 ）運動単位数計測の再現性}

$8 \mathrm{~cm} \times 2 \mathrm{~cm}$ の矩形電極を用いて, 同一被検筋にて 1
日以上の間隔をあけて，最大M波と 10 個の S-MUP を 2 回計測し再現性について検討した。

\section{3 健常者の運動単位数の計測}

前述の計測方法に関する基礎的検討をもとに，表面 電極は $8 \mathrm{~cm} \times 2 \mathrm{~cm}$ の矩形電極を用い，また，表面電 極の位置は筋腹中央に配置することとした．S-MUP は各被検筋ごとに 10 個測定した。

\section{4 頸髄損傷患者の運動単位数の計測}

健常者と同じ方法にて運動単位数を計測した。

\section{結 果}

\section{1 運動単位数計測法における基礎的検討 \\ 1）表面電極の形状の影響}

筋線維方向に幅の異なる電極間 $(8 \mathrm{~cm} \times 2 \mathrm{~cm}, 8$ $\mathrm{cm} \times 0.5 \mathrm{~cm})$ では最大M波, S-MUP の振幅执よび運 動単位数に有意差を認めなかった（表 1)．筋線維の方 向と直角方向に長さの異なる電極では, 最も短い電極 $(2 \mathrm{~cm} \times 0.5 \mathrm{~cm})$ において他の電極 $(4 \mathrm{~cm} \times 0.5 \mathrm{~cm}, 8$ $\mathrm{cm} \times 0.5 \mathrm{~cm})$ より最大M波と S-MUP の振幅が有意 $(\mathrm{p}<0.05)$ に小さい値となった. しかし, 運動単位数 
表 1 表面電極の形状による影響

\begin{tabular}{|c|c|c|c|}
\hline 電極の大きさ & $\mathrm{M}$ 波の振幅 (mV) & S-MUP の振幅 $(\mu \mathrm{V})$ & 運動単位数 \\
\hline $8 \mathrm{~cm} \times 0.5 \mathrm{~cm}$ & $14.7 \pm 3.3$ & $21.2 \pm 4.4$ & $697 \pm 112$ \\
\hline $8 \mathrm{~cm} \times 2 \mathrm{~cm}$ & $14.2 \pm 2.5$ & $21.2 \pm 3.9$ & $669 \pm 92$ \\
\hline $2 \mathrm{~cm} \times 0.5 \mathrm{~cm}$ & $12.5 \pm 4.1 \neg_{*}$ & $20.0 \pm 8.9 \neg_{*}$ & $675 \pm 247$ \\
\hline $4 \mathrm{~cm} \times 0.5 \mathrm{~cm}$ & $\mid 5.3 \pm 3.1-^{*}$ & $25.5 \pm 4.4 \sqcup^{*}$ & $662 \pm 243$ \\
\hline $8 \mathrm{~cm} \times 0.5 \mathrm{~cm}$ & $14.4 \pm 3.4$ & $22.6 \pm 6.4$ & $694 \pm 235$ \\
\hline \multicolumn{4}{|c|}{$\left(n=8\right.$, 平均 $\left.\pm S D,{ }^{*} p<0.05\right)$} \\
\hline
\end{tabular}

M波および S-MUP の振幅は $2 \mathrm{~cm} \times 0.5 \mathrm{~cm}$ の電極にて他の電極より小さい 傾向があり, $2 \mathrm{~cm} \times 0.5 \mathrm{~cm}$ と $4 \mathrm{~cm} \times 0.5 \mathrm{~cm}$ の電極とにおいて有意差を認め た. しかし, 運動単位数にはいずれの電極にても有意差はなかった。

表 2 表面電極の位置による影響

\begin{tabular}{|c|c|c|c|}
\hline 電極の位置 & M波の振幅 (mV) & S-MUP の振幅 $(\mu \mathrm{V})$ & 運動単位数 \\
\hline 中央 & $13.6 \pm 4.4 \longrightarrow$ & $24.2 \pm 8.4 \longrightarrow$ & $660 \pm 414$ \\
\hline $2 \mathrm{~cm}$ 中枢 & $13.1 \pm 4.1 \square^{*}$ & $22.4 \pm 9.9 \square *$ & $697 \pm 366$ \\
\hline $4 \mathrm{~cm}$ 中枢 & $9.4 \pm 3.9=$ & $18.6 \pm 9.5 \beth^{*}$ & $609 \pm 330^{-}$ \\
\hline \multicolumn{4}{|c|}{$\left(\mathrm{N}=10\right.$, 平均 $\left.\pm \mathrm{SD},{ }^{*} \mathrm{p}<0.05\right)$} \\
\hline
\end{tabular}

M波の振幅, S-MUP は運動点中央より $4 \mathrm{~cm}$ 中枢の位置の電極では中央お よび $2 \mathrm{~cm}$ 中枢の位置の電極より有意に低下していた。運動単位数は $4 \mathrm{~cm}$ 中枢の位置の電極にて, $2 \mathrm{~cm}$ 中枢の位置の電極より有意に低下していた.

には有意差を認めなかった。

これらの結果より被記録運動単位の筋内の位置によ る影響が小さいと考えられる $8 \mathrm{~cm} \times 2 \mathrm{~cm}$ の大きさの 矩形電極を表面電極として，本研究では使用すること とした。

\section{2 ) 表面電極の位置の影響}

運動点中央より $4 \mathrm{~cm}$ 中枢に貼付した電極では他の 電極に比べ，最大M波の振幅，S-MUP の振幅が有意 $(\mathrm{p}<0.05)$ に低下した. その運動単位数も小さくなり, 運動点中央より $2 \mathrm{~cm}$ 中枢部の電極から計測された運 動単位数に比べ有意に小さくなった $(\mathrm{p}<0.05$, 表 2$)$. しかし，運動点中央部に貼付した表面電極とそれより $2 \mathrm{~cm}$ 中枢部に貼付した電極とでは最大M波の振幅， $\mathrm{S}$ -MUP の振幅および運動単位数に有意差を認めな かった。したがって，表面電極の位置は，運動点中央 より $2 \mathrm{~cm}$ 程度のずれであれば影響は少ないことがわ かった．よって表面電極は, 運動点の位置とほぼ一致 する上腕二頭筋中央の最大周径部に貼付することとし た。

\section{3 ）運動単位数計測の再現性}

同一被検者から得られた 1 回目および 2 回目の計測 結果は, 最大 $\mathrm{M}$ 波の振幅は $12.2 \pm 1.9 \mathrm{mV}$ および $12.2 \pm$ $1.9 \mathrm{mV}, \mathrm{S}-\mathrm{MUP}$ の振幅は $19.6 \pm 6.8 \mu \mathrm{V}$ および $17.3 \pm$
$4.6 \mu \mathrm{V}$ ，また，運動単位数は $750 \pm 375$ および $777 \pm 335$ となった。

各被検筋の再現性を各被検筋の 2 回の測定値の差を その 2 回の測定值の平均で割った相対差異で表すと, 相対差異の平均はそれぞれ最大M波は $2.8 \pm 2.2 \%, \mathrm{~S}-$ MUP は $34.7 \pm 6.6 \%$, 運動単位数は $33.3 \pm 8.5 \%$ で あった，運動単位数の相対差異の最大值は $49.5 \%$ で あった.

\section{2 健常者の運動単位数}

健常者の最大 $\mathrm{M}$ 波の振幅は，2～17 mV とばらつき が大きかったが, 60 歳未満では年齢に伴う有意な変化 はなく, 60 歳以上で年齢に伴い有意 $(p<0.05)$ に低下 していた(図 3).60歳未満の男女別のM波の振幅は, 男性 $11.2 \pm 1.7 \mathrm{mV}$ ，女性 $9.1 \pm 2.4 \mathrm{mV}$ と男女間に扔い て有意差 $(p<0.05)$ が認められた。 60 歳未満と 60 歳 以上の S-MUP の振幅は $18.3 \pm 7.7 \mu \mathrm{V}$ および $27.7 \pm$ $7.7 \mu \mathrm{V}$ となり, 有意差 $(\mathrm{p}<0.05)$ を認めた（図 4). S-MUP の平均振幅は 60 歳を越えると年齢に伴い増 大する傾向が認められた(図 5).60 歳未満の S-MUP の振幅は, 男性 $19.5 \pm 8.3 \mu \mathrm{V}$, 女性 $18.8 \pm 7.9 \mu \mathrm{V}$ と男 性で大きかったが，統計的には男女の有意差はなかっ た. 


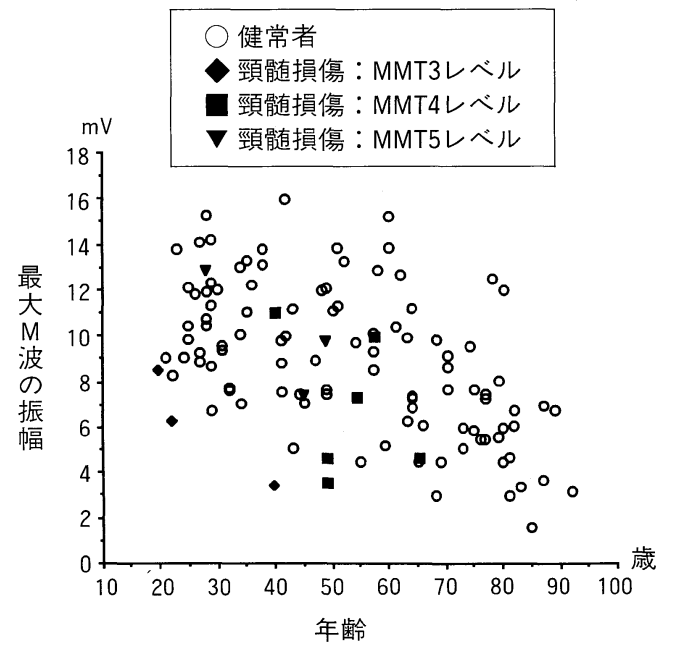

図 3 健常者と頸髄損傷患者における最大M波 の振幅の比較

頸髄損傷患者は残存機能レベルが $\mathrm{C}_{5} \sim \mathrm{C}_{7}$ の完全運動麻痺 患者であり，上腕二頭筋の筋力を徒手筋カテスト (MMT) で5，4，3レベルに分けて比較した。

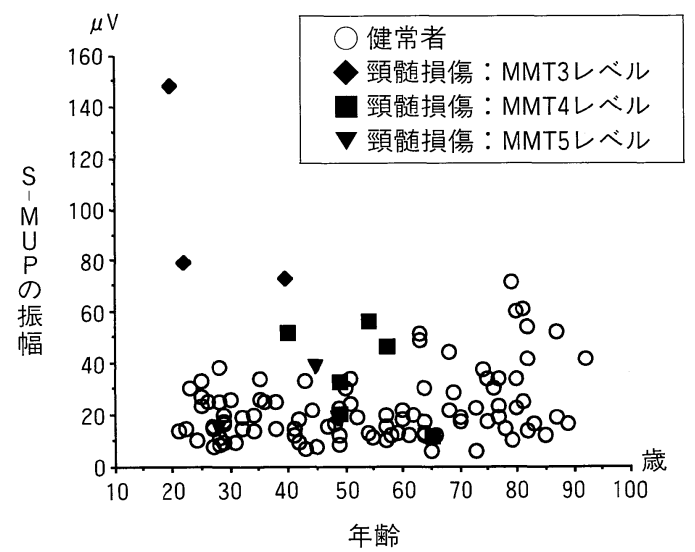

\section{図 5 健常者と頸髄損傷患者における S-MUP} の振幅の比較

運動単位数の減少している頸䯣損傷患者では S-MUP の振 幅が増大している傾向があり, 特にMMT3 レベルの患者で は著しく大きくなっていた。

運動単位数は, 図 6 に示すように 60 歳未満では年 齢と有意な相関は認めなかったが, 60 歳以上では年齢 に伴う有意 $(\mathrm{p}<0.01)$ な減少が認められた。運動単位 数は, 60 歳未満では $631 \pm 219$ で左右間, 男女間には有 意差を認めなかった. 60 歳以上では 60 〜 69 歳が $453 \pm$ 235，70 79 歳が $384 \pm 211 ， 80$ 歳以上が $188 \pm 113$ で あった。

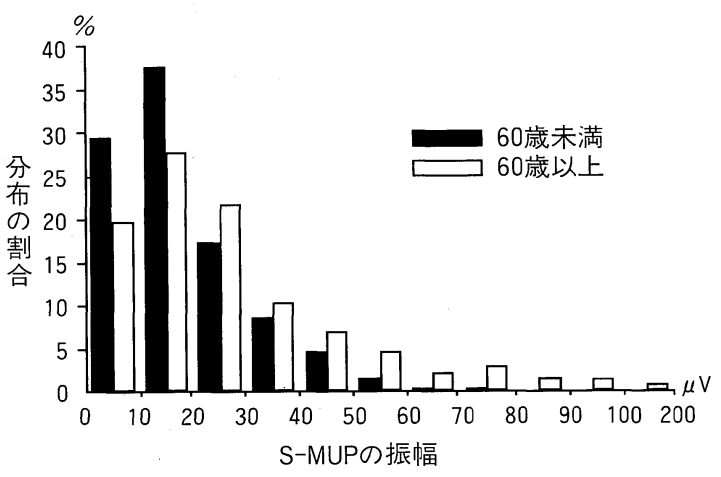

図 4 健常者における全測定 S-MUP の振幅の分布

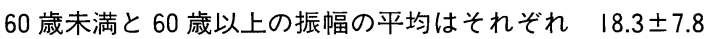
$\mu \mathrm{V}, 27.7 \pm 7.7 \mu \mathrm{V}$ と 60 歳以上群で有意に大きくなり, 60 歳 未満群ではみられない $80 \mu \mathrm{V}$ を越える大きな S-MUP が得 られた。

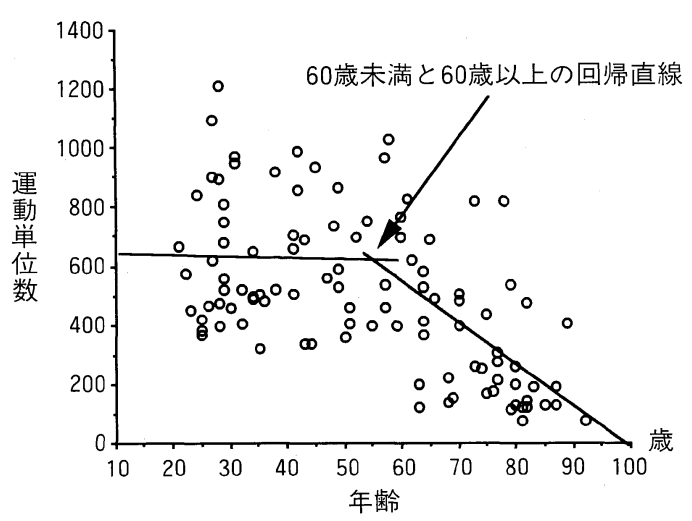

図 6 健常者の年齢と運動単位数

運動単位数はばらつきが大きいが 60 歳以下では運動単位 数の低下傾向はなく, 60 歳を越えると運動単位数の減少傾 向があることがわかる.

\section{3 頸髄損傷患者の運動単位数}

頸髄損傷患者の結果を表 3 に示す，最大M波の振幅 を比較すると頸髄損傷患者において低下傾向がみられ たが，筋力低下が著しくても最大M波の振幅がそれほ ど低下していない筋もあり，筋力との関係は後述する 運動単位数ほど明らかではなかった（図 3).S-MUP の振幅は MMT 3 レベルの 3 肢では著しく大きく なっており，MMT 4 レベルの 6 肢のうち 3 肢におい て明らかな増大があり, 運動単位数の減少している筋 注ど増大する傾向があった（図 5）。

頸髄損傷患者の運動単位数を筋力別に比較すると, 筋力が低下しているほど運動単位数が低下している傾 向があった．特に MMT 3 レベルの 3 肢はすべて運動 単位数が 100 以下と著しく低下し，また MMT 4 レべ 
表 3 頸髄損傷患者の結果

\begin{tabular}{|c|c|c|c|c|c|c|}
\hline 性別 & 年齢 & 受傷後期間 & $\begin{array}{c}\text { 肘座曲力 } \\
\text { (MMT) }\end{array}$ & $\begin{array}{c}\mathrm{M} \text { 波の振幅 } \\
(\mathrm{mV})\end{array}$ & $\begin{array}{c}\text { S-MUP の振幅 } \\
(\mu \mathrm{V})\end{array}$ & 運動単位数 \\
\hline 男 & 20 & 2 年 5 力月 & 3 & 8.5 & 147.6 & 58 \\
\hline 男 & 22 & 4 年 5 力月 & 3 & 6.2 & 78.8 & 79 \\
\hline 男 & 28 & 2 年 6 力月 & 5 & 12.8 & 15.1 & 847 \\
\hline 男 & 40 & 3 年 6 力月 & 3 & 3.3 & 73.0 & 45 \\
\hline 男 & 40 & 3 年 6 力月 & 4 & 11.0 & 52.8 & 208 \\
\hline 男 & 45 & 12 力月 & 5 & 7.3 & 38.8 & 188 \\
\hline 女 & 49 & | 年 9 カ月 & 4 & 4.6 & 33.2 & 139 \\
\hline 男 & 49 & | 年 9 力月 & 4 & 3.5 & 20.6 & 172 \\
\hline 男 & 49 & 9 年 7 カ月 & 5 & 9.6 & 18.2 & 527 \\
\hline 男 & 54 & 6 力月 & 4 & 7.3 & 56.5 & 129 \\
\hline 男 & 57 & 6 力月 & 4 & 9.9 & 46.8 & 211 \\
\hline 女 & 65 & 10 力月 & 4 & 4.6 & 12.3 & 375 \\
\hline
\end{tabular}

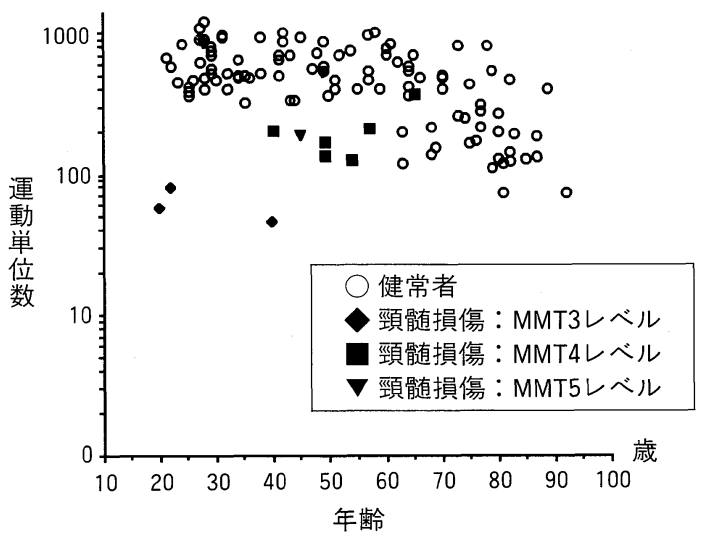

図 7 健常者と頸髄損傷患者における運動単位 数の比較

MMT3 レベルの患者では運動単位数がすべて 100 以下にな り，著しく低下していた。（運動単位数は対数目盛）

ルの 6 肢のうち 5 肢, MMT 5 レベルの 3 肢のうち 1 肢において軽度低下していた（図 7)。

\section{考察}

\section{1 運動単位数計測法における基礎的検討}

\section{1 ）表面電極の形状の影響}

今回, 形状の異なる電極を用いて運動単位数を算出 したが，その結果には有意差が出なかった．筋線維と 直角方向に短い表面電極では，S-MUP の平均振幅が 小さく測定されたが，最大M波の振幅も同様に小さく 計測されるため, 運動単位数には有意差が出なかった。 しかし，計測した個々の S-MUP を比較すると，小さ
な表面電極では被測定運動単位の位置による影響がよ り大きく，電極から離れた運動単位の S-MUP は低振 幅に計測される傾向があった.

上腕二頭筋の同一運動単位に含まれる筋線維の横断 面上の分布は，平均 $5.1 \mathrm{~mm}$ の領域と報告 ${ }^{17)}$ されてお り，各運動単位の筋内の位置は比較的小さな範囲に限 定されている，筇深部に位置する運動単位や表面電極 より離れている筋の内外側の運動単位の S-MUP が 小さく測定されたのは，表面電極との距離の影響が大 きいと思われ，特に小さい表面電極ではその影響が大 きくなるものと考えられた。

\section{2 ）表面電極の位置による影響}

上腕二頭筋の運動点は筋腹中央の $1 / 3$ に 字状に分 布し ${ }^{1,10)}$, 各筋線維は単一の運動単位により支配されて おり，筋腹中央で途切れることはなく連続していると 報告されている ${ }^{18)}$.よって本研究で施行したごとく, 表 面電極の貼付位置が運動点中央より $2 \mathrm{~cm}$ の偏りでは 測定位置の筋横断面に含まれる運動単位数は同じであ り，このことは本研究で計測された運動単位数の差が 小さいという結果とも一致している.

\section{3 ) 運動単位数計測の再現性}

本研究の再現性は, Bromberg らのトリガー法の再 現性に関する報告4)とほぼ一致する結果となった。最 大M波の再現性に関しては満足すべき結果が得られ た。しかしながら， S-MUP の振幅の再現性は最大M 波より低く，そのため運動単位数の再現性は主に SMUP の測定值に左右されることになった.

S-MUP は表面電極と運動単位領域の距離に影響さ れ，また，同じ筋内でもより表在する運動単位ほど大 きくなるとの報告 ${ }^{11}$ があるため，トリガー信号を導出 
する針電極はできるだけ記録位置が偏らないように注 意を払った。しかし，計測される運動単位の位置の偏 りは完全には避けられない。 また，運動単位の大きさ と筋力の発火閾值に相関があるという大きさの原理 (size principle) が存在し ${ }^{19}$, 同一筋内の運動単位の大 きさには数倍の差があると考えられている ${ }^{27)}$. 再現性 の研究における 2 回の S-MUP 測定時の上腕二頭筋 の微小収縮に微妙な差があり, それが被計測運動単位 の大きさに影響した可能性が示唆された.

一方, McComas らが筋萎縮性側索硬化症において は, 運動単位数が正常の $10 \%$ 以下になって初めて臨床

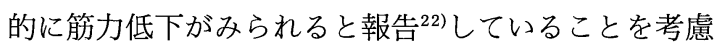
すれば，本研究での運動単位数の再現性は，頸髄損傷 患者における運動単位数と筋力の評価に関する臨床応 用には足りうる。

\section{2 健常者の運動単位数}

運動単位の計測方法に関して, Feinstein は, 組織学 的に神経線維を数元, 健常成人の第 1 背側骨間筋, 虫 様筋，腕橈骨筋の運動単位数をそれぞれ 119，95，410 と報告した ${ }^{18)}$. Buchthal は Christensen の報告 ${ }^{10)}$ から 再計算し, 死産児の上腕二頭筋の運動単位数を 744 と 報告した ${ }^{8)}$. Tsukagoshi らは，前角細胞の核をすべて 数え, 第 6 頸髄節に含まれる $\alpha$ 運動神経の数は健常成 人では，2,006〜3,889 と報告した ${ }^{29)}$.

一方, 1970 年代より電気生理学的方法によって, 刺 激漸増法により短趾伸筋，母指球筋，小指球筋などの 四肢末梢の筋の健常成人の運動単位数計測が行われ, 概ね 200〜400 と報告された ${ }^{23,25,26)}$.また, Brown らは トリガー法を用いて上腕二頭筋の運動単位数を計測 し, 60 歳以下の運動単位数は平均 911 であると報告し $た^{7)}$.

本研究はトリガー法を用いて上腕二頭筋の運動単位 数を計測し, 60 歳未満の運動単位数は平均 631 とな り，これは上記の報告とほぼ合致する結果となった。

本研究で計測した健常者の上腕二頭筋の運動単位数 は，60歳を境にして減少がみられた。これは，組織学 的報告 ${ }^{28)}$ および電気生理学的報告 ${ }^{6,7,9)}$ とも一致する. 60 歳を越えてからの運動単位数の減少は, 高齢者の筋 力低下の主な原因の一つと考えられている ${ }^{14,30)}$.

最大M波と S-MUP の振幅が女性において小さい 傾向があったのは, 筋線維および筋自体の太さの違い, 皮下脂肪の厚さなどが要因として考えられる.しかし，
運動単位数の計測には影響がなかったことより運動単 位数の男女差はないと考えられる。

今回用いたトリガー法による運動単位数の計測に は，同期発火 (synchronization) ${ }^{33)}$ ，位相の打ち消し (phase cancellation) ${ }^{20)}$ および前述した運動単位動員 における大きさの原理など方法論上の問題点があるこ とにも留意しなければならない。同期発火は，今回 S -MUP を計測した際のような微小収縮時には少ない と考えられている。また，位相の打ち消しの影響も， 電気刺激位置が筋から近いこと，個々の S-MUP の位 相に大きな差異がないことから運動単位計測上大きな 問題とはならないと思われる，大きさの原理により早 く出現する運動単位と強く収縮した時に出現する運動 単位は異なり，その振幅も異なる可能性がある，本研 究では，弱収縮で行われたため早く収縮する比較的小 さい一部の運動単位を反映している可能性があり，そ れらの運動単位電位の振幅には一定の偏りが出る可能 性は否定できない，動員閾值と S-MUP の大きさとの 定量的関係は現在十分解明されておらず，大きさの原 理がどの程度運動単位数の計測に影響しているかは今 後の課題と思われる.

\section{3 頸髄損傷患者の運動単位数}

完全運動麻痺の頸髄損傷患者における損傷レベル周 辺の筋力回復を損傷レベル周辺の筋力より予測する研

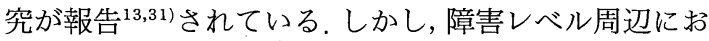
ける筋力回復の機序や筋力回復に重要な要素と思われ る残存運動単位数を測定した報告は皆無といえる。そ して, 過去において頸䯣損傷患者の運動単位数を計測 した報告は少なく，刺激漸増法により損傷レベル以下 の完全麻痺患者の母指球筋または短趾伸筋において減 少していたとの報告3,32)があるのみである。

頸髄損傷患者の損傷レベル周辺での筋力回復の機序 としては神経再支配, 残存神経の発芽現象, 残存神経 の発火様式の変化および筋線維の肥大化が考えられて いる ${ }^{211}$. 部分的脱神経に起因する運動単位の代償的増

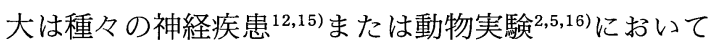
観察されてはいるが，人間においてその代償機能がぞ の程度あり受傷後いつ頃までに完成するか，また，筋 力にどの程度影響するかなどは十分には究明されてい ない.

本研究の結果より, 慢性期における頸髄損傷の完全 運動麻痺患者の上腕二頭筋の筋力は残存運動単位数が 
100 以下では MMT 3 レベル以下の著しい筋力低下と なることが示唆された. したがって, 残存運動単位数 を受傷早期より計測することにより，頸髄損傷の境界 領域での筋力回復の予測が可能と思われる.

われわれが今回用いた上腕二頭筋の運動単位数の計 測法は, 頸髄損傷患者の部分的脱神経の定量的評価が 可能であり, 筋力回復の予測, そのメカニズムの解明, 筋力増強法の検討などリハビリテーション医学の基礎 的ならびに臨床的研究に寄与することは大きいと思わ れる。

稿を終えるにあたり,ご指導, ご校閲を頂いた慶應義塾大 学医学部リハビリテーション科 千野直一教授ならびに永 田雅章博士, 野田幸男博士, 正門由久講師に深謝致します。

本論文の一部は, 第 27 回日本リハビリテーション医学会 (福岡, 1990 年), 第 25 回日本パラプレジア医学会 (米子, 1990 年), 第 28 回日本リハビリテーション医学会 (東京, 1991 年), 第 29 回日本リハビリテーション医学会 (神戸, 1992 年), 第 30 回日本リハビリテーション医学会（仙台, 1993 年), 第 23 回日本脳波・筋電図学会 (鹿児島, 1993 年) において発表した。

\section{文 献}

1) Aquilonius S, Askmark H, Gillberg P, Nandedkar $\mathrm{S}$, et al : Topographical localization of motor endplates in cryosections of whole human muscles. Muscle Nerve 7:287-293, 1984.

2) Blight AR, Young $W$ : Central axons in injured cat spinal cord recover electrophysiological function following remyelination by schwann cells. J Neurol Sci $91:$ 15-34, 1989.

3) Brandstater ME, Dinsdale SM : Electrophysiological studies in the assessment of spinal cord lesions. Arch phys Med Rehabil 57:70-74, 1976.

4) Bromberg MB: Motor unit estimation: reproducibility of the spike-triggered averaging technique in normal and ALS subjects. Muscle Nerve 16: 466-471, 1993.

5) Brown MC, Ironton $R:$ Sprouting and regression of neuromuscular synapses in partially denervated mammalian muscles. J physiol $278: 325-348,1978$.

6) Brown WF : A method for estimating the number of motor units in thenar muscles and the canges in motor unit count with ageing. J Neurol Neurosurg Psychiatry $35: 845-852,1972$.

7) Brown WF, Strong MJ, Snow R: Method for estimating numbers of motor units in biceps-brachialis muscles and losses of motor units with aging. Muscle Nerve 11:423-432, 1988.

8) Buchthal $\mathrm{F}$ : The general concept of the motor unit. Neuromuscular disorders. Res Publ Assoc Res Nerv Ment Dis 38:3-30, 1961.

9) Campbell MJ, McComas AJ, Petito F : Physiologi- cal changes in aging muscles. J Neurol Neurosurg Psychiatry 36:174-182, 1973.

10) Christensen $E:$ Topography of terminal motor innervation in striated muscles from stillborn infants. Am J Phys Med 38:65-78, 1959.

11) Clamann HP : Activity of single motor units during isometric tension. Neurology 20:254-260, 1970.

12) De Koning P, Wieneke GH, Spijk D, Huffeken AC, et al: Estimation to the number of motor units based on macro-EMG. J Neurol Neurosurg Psychiatry $51: 403-411,1988$.

13) Ditunno JF, Stover SL, Freed MM, Ahn JH : Motor recovery of the upper extremities in traumatic quadriplegia ; a multicenter study. Arch Phys Med Rehabil 73 : 431-436, 1992.

14) Doherty TJ, Vandervoort AA, Tauylor AW, Brown WF : Effects of motor unit losses on strength in older men and women. J Appl Physiol 74:868874, 1993.

15) Gootzen $T$, Vingerhoets $D$, Stegeman D : A study of motor unit structure by mean of scanning EMG. Muscle Nerve 15:349-357, 1992.

16) Edds MV, Small WT: The behavior of residual axons in partially denervated muscles of the monkey. J Exp Med 93: 207-216, 1951.

17) Erminio F, Buchthal F, Rosenfalck P : Motor unit territory and muscle fiber concentration in paresis due to peripheral nerve injury and anterior horn cell involvement. J Neurol Neurosurg Psychiatry $33: 657-671,1959$.

18) Feinstein $B$, Lindergård $B$, Nyman $E$, Wohlfart $G$ : Morphologic studies of motor units in normal human muscles. Acta Anat $23: 127-142,1955$.

19) Henneman E, Somjen G, Carpenter DO : Functional significance of cell size in spinal motoneurons. J Neurophysiol 28:560-580, 1965.

20) Lee RG, Ashby P, White DG, Aguayo J : Analysis of motor conduction velocity in the human median nerve by computer simulation of compound muscle action potentials. Electroencephalogr Clin Neurophysiol 39: 225-237, 1975.

21) Mange KC, Marino RJ, Gregory PC, Herbison GJ, et al: Course of motor recovery in the zone of partial preservation in spinal cord injury. Arch Phys Med Rehabil 73: 438-441, 1992.

22) McComas AJ, Sica REP, Campbell MJ, Upton RM : Functional compensation in partially denervated muscles. J Neurol Neurosurg Psychiatry 34:453-460, 1971.

23) McComas AJ : Invited review : Motor unit estimation: methods, results, and present status. Muscle Nerve 14:585-597, 1991.

24) McComas AJ, Fawcett PRW, Campbell MJ, Sica EP : Electrophysiological estimation of the number of motor units within a human muscle. J Neurol Neurosurg Psychiatry 34:121-131, 1971.

25) Slawnych MP, Laszlo CA, Hershler C : A review of 
techniques employed to estimate the number of motor units in a muscle. Muscle Nerve 13:10501064, 1990.

26) Stein RB, Yang JF : Method for estimating the number of motor units in human muscles. Ann Neurol 28:487-495, 1990.

27) Stålberg E: Electrodiagnostic assessment and monitoring of motor unit changes in disease. Muscle Nerve 14:293-303, 1991.

28) Tomlinson BE, Irving $\mathrm{D}$ : The numbers of limb motor neurons in human lumbosacral cord throughout life. J Neurol Sci 34:213-219, 1977.

29) Tsukagoshi H, Yanagisawa N, Oguti K, Nagashima $\mathrm{K}$, et al: Morphometric quantification of the cervical limb motor cells in controls and in amyotrophic lateral sclerosis. J Neurol Sci 41 : 287-297, 1979.

30) Vandervoort AA, McComas AJ : Contractile changes in opposing muscles of the human ankle joint with aging. J Appl Physiol 61:361-367, 1986.

31) Waters RL, Adkins RH, Yakura JS, Sie I : Motor and sensory recovery following complete tetraplegia. Arch Phys Med Rehabil 74 : 242-247, 1993.

32) Yang JF, Stein RB, Jhamandas J, Gordon $T$ : Motor unit numbers and contractile properties after spinal cord injury. Ann Neurol 28:496-502, 1990.

33）正門由久, 千野直一：Motor unit synchronization. 臨 床脳波 34：380-384, 1992 .

\title{
Estimating the Number of Motor Units in Brachial Biceps Muscles of Normal Subjects and Cervical Spinal Cord Injury Patients
}

\author{
by
}

\section{Ken Kondo}

from

Department of Rehabilitation Medicine, Keio University School of Medicine

(Jpn J Rehabil Med $32: 367-375,1995)$

Motor units estimates (MUEs) of the brachial biceps muscles of chronic motor complete quadriplegic patients $(\mathrm{C} 5-\mathrm{C} 7)$ were compared to those of normal subjects using a spike-triggered averaging technique. In each subject, a surface-recorded maximum compound muscle action potential (M potential) was first evoked by stimulation of the musculocutaneous nerve at the axillary fold. Ten different surface single motor unit action potentials (S-MUP) were then computed by triggering an average of surface EMG with the motor unit action potential recorded by a needle electrode inserted to different locations within the muscle. The MUE was calculated by division of the amplitude of the M potential by the mean amplitude of the SMUPs.

The influences of surface electrode shape and location on MUE in normal muscles were evaluated, and it was also verified that the technique was sufficiently reproducible to evaluate partially denervated muscles of quadriplegic patients. In the main study, 102 normal muscles and 12 muscles of quadriplegic patients (of which three were fair, six were weak and three were normal in strength) were examined. The MUEs of the normal muscles were relatively constant (average MUE \pm 1 standard deviation, 631 \pm 219 ) up to the age of 60 , but thereafter decreased in proportion to age. The MUEs of the quadriplegic patients were reduced according to muscle strength ; for example, the MUEs of the muscles with fair strength were all less than 100 .

The method utilized in this study can be used to quantitatively evaluate partially denervated brachial biceps muscles of quadriplegic patients. It should be useful for studying the mechanisms of motor recovery in this population, for estimating eventual strength at an early stage following injury, and for evaluating the effects of muscle training. 